\title{
PENGEMBANGAN BUKU PANDUAN MODEL BLENDED LEARNING BERBASIS WEBBLOG
}

\author{
Jajang S. ${ }^{1)}$ dan I Ketut Supir ${ }^{2)}$ \\ Jurusan Seni dan Desain, Fakultas Bahasa dan Seni \\ Universitas Pendidikan Ganesha, Singaraja, Indonesia \\ e-mail: jajang.suryana@undiksha.ac.id ${ }^{1}$; ketut.supir@undiksha.ac.id ${ }^{2}$
}

\begin{tabular}{|l|c|c|}
\hline (C) $(0)$ & \multicolumn{3}{|c|}{$\begin{array}{l}\text { This is an open-access article under the CC BY-SA license. } \\
\text { Copyright (0) } 2020 \text { by Author. Published by Universitas Pendidikan Ganesha. }\end{array}$} \\
\hline Received : May, 2020 & Accepted : June, 2020 & Published : June, 2020 \\
\hline
\end{tabular}

\begin{abstract}
ABSTRAK
Penelitian ini adalah penelitian pengembangan. Pengembangan dimaksud bertalian dengan main product revision, yaitu perancangan buku panduan Model Blended Learning Berbasis Webblog. Metode yang digunakan dalam penelitian ini adalah metode penelitian pengembangan yang berbasis FGD dan angket reviewer mendalam sebagai alat evaluasi. Hasil FGD dan angket reviewer mendalam dari sejumlah ahli dan calon pengguna buku pedoman, ditetapkan bahwa 1) format buku pedoman yang ergonomis adalah A5; 2) isi bahasan buku sebagian disusun dalam format bahasan tutorial sejalan dengan fungsi buku pedoman; 3) ukuran halaman A5 masih memberi ruang yang nyaman untuk pembacaan gambar-gambar bahan tutorial hasil screenshot; 4) layout naskah rata kiri-kanan dengan kepala alinea rata kiri dianggap cukup nyaman; 5) cover buku yang polos dianggap cukup eye-catching dengan penggunaan huruf sans serif; dan 6) font dengan rata tengah pada tampilan cover buku dianggap lebih nyaman.
\end{abstract}

Kata-kata kunci: blended learning, webblog, pengembangan, buku pedoman

\begin{abstract}
Research is development research. Development referred to the main product revision, which is the design of the Model Blended Learning manual based Webblog. The methods used in this study are the research methods of development based on FGD and in-depth reviewer as an evaluation tool. FGD results and an in-depth reviewer of a number of expert and prospective user manuals, defined that 1) the ergonomic format of the manual is A5;2) The content of the book is partially compiled in the tutorial discussion format in line with the manual function; 3) A5 page size still gives a comfortable space for the reading of the tutorial material images screenshot results; 4) The flat-left-right script layout with the left align head is considered quite comfortable; 5) The plain book cover is considered quite eye-catching with the use of sans serif letters; and 6) fonts with the middle align on the book cover view is considered more convenient.
\end{abstract}

Keywords: blended learning, webblog, development, manual book

\section{PENDAHULUAN}

Pengembangan model blended learning berbasis webblog di Prodi D-3 Desain Komunikasi Visual (PD-3DKV) dan Pendidikan Seni Rupa (PSR), Jurusan Seni dan 
Desain (JSdD), FBS-Undiksha, telah beberapa kali dilaksanakan. Khusus pelaksanaan pembelajaran di PD-3DKV telah dilakukan hingga ke tahap main product revision.

Revisi produk kegiatan telah dilakukan menyangkut tiga hal yang menjadi pokok pemeriksaan --memanfaatkan pola pendekatan Chiesa \& Frattini (2009)-- yaitu menyangkut perintang input (hasil inventarisasi dan kajian teori), proses (pengembangan model pembelajaran), dan output (rumusan langkah kegiatan pembelajaran). Analisis input menyangkut karakter mahasiswa dan karakter mata kuliah PD-3DKV FBS, Undiksha. PD-3DKV pada dasarnya adalah prodi yang memiliki kajian dominan bidang kebahasaan. Bidang kajian kebahasaan dimaksud adalah bahasa visual (bahasa gambar) maupun tulis dan (seharusnya juga: bahasa verbal) lisan. Tetapi, kesadaran tentang karakter kebahasaan milik bidang kajian desain komunikasi visual ini, belum banyak dimanfaatkan sebagai basis kegiatan pembelajaran.

Di lapangan, mahasiswa PD-3DKV FBS, Undiksha, baru memiliki kesadaran yang didominasi kebahasaan visual (khusus bahasa gambar). Padahal ada sejumlah mata kuliah yang menuntut mereka untuk siap menjadi pengguna bahasa tulis dan lisan. Penulisan Naskah Produksi dan Copy writing, Desain Komunikasi Visual (desain poster, infografis, baliho, dan barang cetak lainnya), Tinjauan Desain, Tinjauan Seni, maupun dalam sejumlah kegiatan presentasi (penulisan proposal, pemaparan rancangan karya, maupun kegiatan diskusi pameran) adalah jenis mata kuliah yang kental dengan bahasan kebahasaan tulis maupun lisan.

Isi kurikulum PD-3DKV FBS, Undiksha, terdiri atas dua karakter utama mata kuliah: mata kuliah teoretis dan praktis. Mata kuliah teoretis lebih banyak melibatkan kajian-kajian pengetahuan dasar dan teori desain seperti Tinjauan Desain, Tinjauan Seni, Psikologi Komunikasi, Sejarah Desain, dan lain-lain. Mata kuliah praktis, mata kuliah yang lebih menuntut keterampilan penggubahan seperti Desain Komunikasi Visual, Audio Visual, Fotografi, Animasi, Ilustrasi, Gambar Teknik, Gambar Bentuk, dan sejumlah mata kuliah praktik lainnya, isinya dominan menuntut pengalaman-pengalaman mahasiswa dalam pengembangan "keterampilan tangan". Di antara kedua karakter mata kuliah tadi, masih ada mata kuliah tertentu yang tuntutannya seimbang antara penguasaan teori dan praktik, seperti Penulisan Naskah Produksi dan Copy writing serta Bahasa Visual.

Karakter mata kuliah sangat berpengaruh kepada jenis dan bentuk tugas latihan yang harus diselesaikan oleh mahasiswa. Tugas-tugas latihan yang harus diselesaikan oleh mahasiswa PD-3DKV terdiri atas tiga jenis dan bentuk. Pertama, tugas yang sepenuhnya menuntut mahasiswa terampil mengolah tulisan dan lisanan. Kedua, tugastugas latihan yang menuntut keterampilan berkarya seperti menghasilkan rancangan berupa poster, baliho, banner, spanduk, infografis, foto, video, animasi, dan sejenisnya. Ketiga, tugas-tugas latihan yang melingkupi dua tuntutan tadi: tulisan (juga lisanan) dan karya seperti pada tugas copy writing. Tuntutan karakter mata kuliah tadi pada akhirnya akan menghasilkan ragam jenis dan bentuk tugas yang harus diselesaikan oleh mahasiswa PD-3DKV FBS, Undiksha.

Karakter dominan mahasiswa PD-3DKV FBS, Undiksha, lebih menyukai pekerjaan (tugas) berbasis media aplikasi komputer. Penggunaan perangkat kerja komputer dalam pengelolaan tugas lebih disukai oleh mereka. Sisi positif tersebut harus dimanfaatkan dalam proses pembelajaran. Pembelajaran yang menyertakan penggunaan perangkat kerja komputer adalah model pembelajaran yang bisa mewadahi kondisi tadi. 
Berdasarkan hasil diskusi-diskusi antardosen, ada kekhawatiran bahwa kesukaan mahasiswa kepada perangkat kerja berbasis komputer telah menyebabkan mereka malas berlatih keterampilan yang mengutamakan kepandaian tangan (kerja manual). Keterampilan kerja manual menjadi inti tuntutan utama pada mata-mata kuliah dasar. Kondisi dan tuntutan tadi harus mendapatkan jalan keluar yang baik agar pada akhirnya mahasiswa memiliki keterampilan yang seimbang, manual (mengandalakan keterampilan tangan) maupun digital (menggunakan perangkat kerja komputer). Di samping hal itu, ada tuntutan penting yang juga harus dipenuhi yaitu keterampilan mengomunikasikan isi rancangan kegiatan maupun karya kepada klien.

Model pembelajaran yang efektif memadukan tiga sisi keterampilan tersebut adalah model blended learning. Tuntutan pembelajaran jenis ini adalah menggabungkan jenis kegiatan yang manual (di dalamnya ada kegiatan-kegiatan yang menuntut keterampilan menuliskan gagasan), digital (keterampilan memanfaatkan software berbasis komputer), maupun tuturan (presentasi ide dan maksud desain). Banyak hasil pengembangan model blended learning menggunakan webblog (blog) hanya sebagai media pembelajaran tambahan. Webblog difungsikan sekadar kontainer materi ajar (contoh dalam pembelajaran matematika) yang disediakan oleh dosen (Sunismi dan Abdul Halim Fathani, 2017). Mahasiswa tidak dilibatkan di dalam pengelolaan isi webblog. Ada juga pembelajaran menggunakan webblog sebagai kontainer tugas mahasiswa dalam materi pembelajaran menulis berbahasa Perancis (Darmawangsa, 2014). Khusus untuk pembelajaran bidang desain komunikasi visual (materi pembelajaran teori sekalipun) hingga tahun 2019, belum ditemukan yang memanfaatkan webblog sebagai bagian dari materi pembelajaran.

Blended learning yang sudah dilaksanakan di PD-3DKV maupun PSR adalah memungsikan webblog sebagai kontainer tugas-tugas mahasiswa. Dalam pelaksanaan model pembelajaran yang lengkap, dosen harus memiliki webblog induk materi ajar. Dosen juga harus menyiapkan sejumlah daftar link materi yang bisa diakses oleh mahasiswa. Mahasiswa membuat webblog untuk merespons tugas-tugas yang diberikan oleh dosen. Semua tugas baik dalam format tulisan maupun gambar dan video, disimpan secara bertahap dalam webblog masing-masing mahasiswa. Webblog mahasiswa, selain berfungsi sebagai kontainer data tugas juga digunakan sebagai tempat memamerkan karya mereka. Pameran daring adalah pameran tanpa batas ruang dan waktu yang bisa diakses siapapun dan kapanpun.

Bahan buku telah terkumpul berupa data hasil penelitian pengembangan sebelumnya terutama menyangkut penyesuaian tentang hal-hal baru yang bertalian dengan tata kelola webblog dan cara mengakses google.com sebagai vendor layanan utama yang harus mengalami beberapa update. Hal lain yang menjadi tuntutan dalam KKNI, perlu diwadahi juga dalam penyusunan isi buku pedoman ini. Semua hal itu memengaruhi format buku pedoman pelaksanaan model blended learning berbasis webblog yang sejalan dengan kondisi Jurusan Seni dan Desain. 


\section{Road Map Penelitian Pembelajaran Berbasis Webblog}

Tahun 2011/2012 Prodi PSR FBS, Undiksha,

- Mengakses webblog pembelajaran milik dosen dan sejumlah webblog maupun website (hasil pencarian dosen) yang memiliki materi sejalan dengan bahankuliah : prinout bahan diskusi

\section{Tahun 2016/2017}

Prodi DKV FBS,

Undiksha, dan Prodiprodi yang menyelenggarakan MPK Pendidikan Agama Islam di FBS, Undiksha,

- Menggunakan webblog sebagai kontainer tugas mingguan (kendali tanda hadir kuliah) dan portofolio tugas bahan

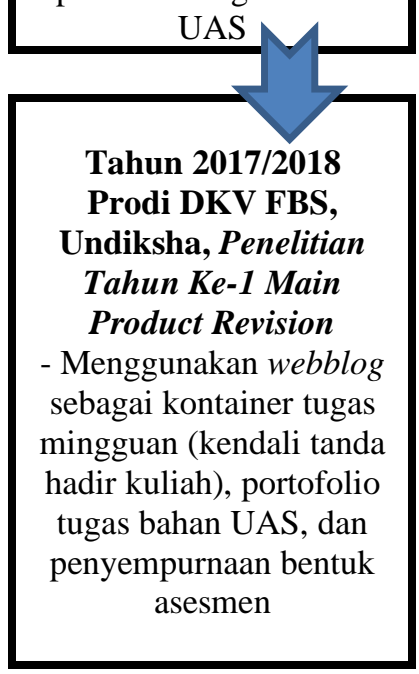

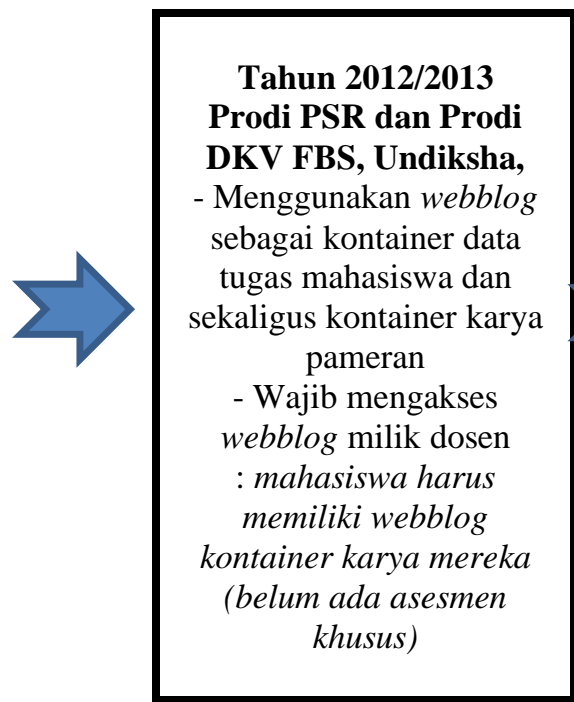

Tahun 2015/2016

Prodi DKV FBS, Undiksha, dan Prodiprodi yang menyelenggarakan MPK Pendidikan Agama Islam di luar FBS, Undiksha, -Menggunakan webblog sebagai kontainer tugas mingguan (kendali tanda hadir kuliah) dan portofolio tugas bahan UAS

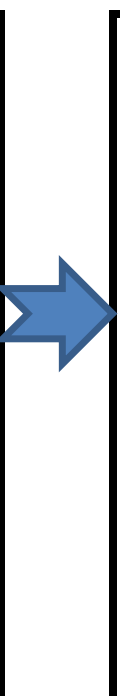

Tahun 2013/2014 Prodi PSR dan Prodi DKV FBS, Undiksha,; Prodi PGSD FIPUndiksha

- Menggunakan webblog sebagai kontainer data tugas mingguan lebih terencana sebagai pelengkap blended learning: asesmen pembelajaran terencana berbasis webblog dan mulai menggunakan pola pembelajaran tertentu

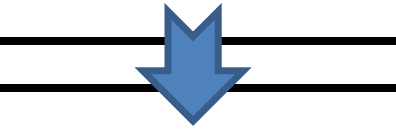

Tahun 2014/2015

Prodi PSR, Prodi DKV, dan Prodi-prodi yang menyelenggarakan MPK Pendidikan Agama Islam di FBS, Undiksha,

- Menggunakan webblog sebagai kontainer data tugas mingguan: tugas mingguan sekaligus sebagai kendali kehadiran kuliah

Bagan 1. Road Map Penelitian Pembelajaran Berbasis Webblog 


\section{PRASI JURNAL BAHASA, SEN, DAN PENGGARRAWNA}

VOL. 15 | No. 01 | Juni 2020

ISSN: Print 1693-6124 - Online 2614-1116

Undiksha| DOI: http://dx.doi.org/10.23887/prasi.v15i01.24828 |https://ejournal.undiksha.ac.id/index.php/PRASI

\section{Permasalahan Blended learning Berbasis Webblog}

Di samping hal-hal positif yang telah ditemukan di lapangan, ada hal lain yang memerlukan perubahan. Perubahan dimaksud adalah perubahan yang diperkirakan akan memperbaiki kekurangan-kekurangan dan menambahi hal-hal baru yang dianggap perlu. Perubahan maupun penambahan menjadi bahan pertimbangan asesmen akhir kegiatan. Perubahan yang harus direncanakan adalah mengenai 1) pola pemeriksaan hasil pekerjaan mahasiswa, 2) cara menyampaikan balikan kepada mahasiswa, dan 3) batasan waktu yang mengikat kedisiplinan mahasiswa dalam mengunggah tugas. Sementara itu, penambahan yang melengkapi kegiatan adalah 1) penyediaan template isi unggahan, 2) penyediaan sumber rujukan yang bisa diakses oleh mahasiswa, dan 3) pola reward yang dijanjikan kepada mahasiswa yang memiliki unggahan terbaik dan lengkap.

Sejumlah permasalahan teknis muncul dalam isi webblog yang dibuat oleh mahasiswa, di antaranya tata letak halaman webblog yang kurang eye catching, padahal Google sebagai vendor telah mempersyaratkan hal itu (tampilan webblog yang ramah, mudah dialihtampilkan antara layar komputer maupun handphone dan tablet). Oleh karena itu Google telah menyediakan webblog templates yang bisa digunakan. Bahkan, Google pun (dalam hal ini, Blogger) menyediakan sejumlah fitur tampilan yang telah dipola agar mudah menggunakannya.

Masalah teknis lainnya yang muncul adalah pola kebiasaan copy-paste yang dilakukan oleh mahasiswa seperti yang ditunjukkan gambar 1. Ada kendala tampilan yang sangat mengganggu pada kondisi tertentu tentang pola tampilan tulisan (huruf, susunan baris, maupun warna latar) yang menunjukkan indikator bahwa tulisan tersebut hasil copy-paste. Misalnya baris tulisan yang tidak bisa disesuaikan dengan baris tulisan yang ditempeli hasil paste. Begitupun ketika mahasiswa menempelkan tulisan dengan jenis huruf khusus Arab, Jepang, Cina dan sejenisnya yang memiliki pola tata susun huruf yang sangat berbeda.

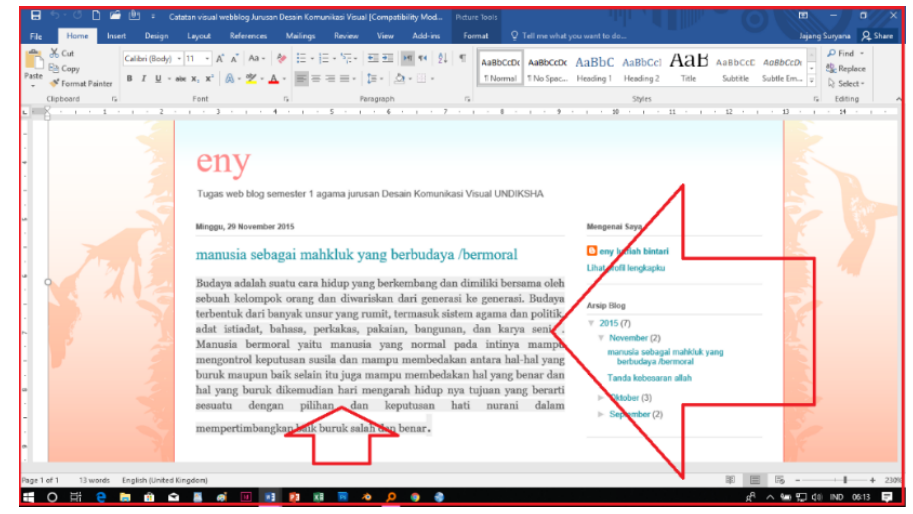

Gambar 1. Salah satu contoh screenshot tampilan webblog mahasiswa dengan indikator tulisan hasil copy-paste: warna yang melatari tulisan dan perapihan baris yang tidak tertib.

Pemeriksaan webblog mahasiswa memerlukan waktu khusus. Catatan tentang alamat webblog mahasiswa menjadi sangat penting untuk disimpan oleh dosen. Banyak mahasiswa yang tidak tertib menyimpan data penting miliknya. Ketika mereka akan mengakses isi webblog, tidak jarang mahasiswa yang kehilangan alamat webblog maupun 
catatan lainnya seperti alamat e-mail dan password-nya. Begitupun ketika hasil pemeriksaan akan dikomunikasikan kepada mahasiswa, dosen memerlukan alamat mahasiswa yang bisa digunakan untuk menyampaikan komentar maupun tuntutan (gambar 2). Alamat e-mail dan nomor handphone menjadi sangat penting sebagai sarana mengomunikasikan hasil tinjauan tugas mahasiswa oleh dosen.

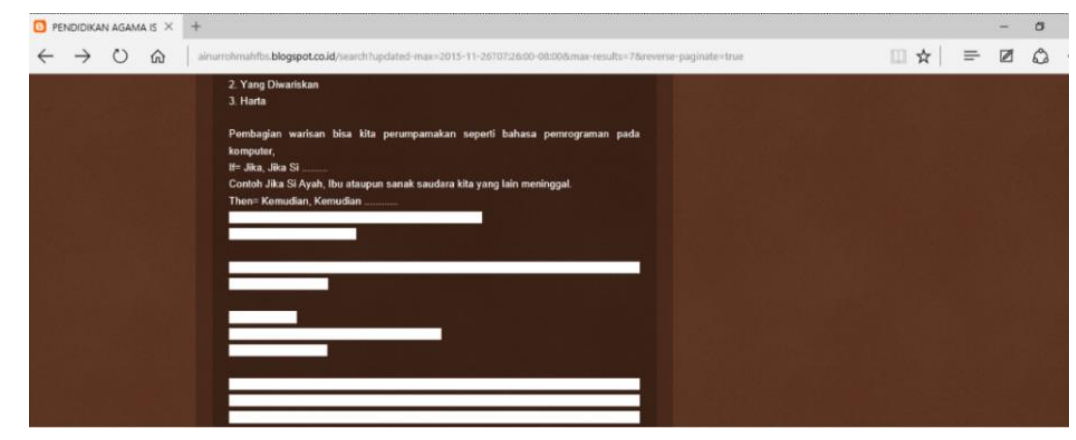

Gambar 2. Contoh screenshot pengunggahan tulisan hasil copy-paste yang salah perhitungan.

Ada beberapa hal yang ditemukan di lapangan, terkait dengan pola pemeriksaan webblog mahasiswa, format tulisan dalam webblog, teknik pemeriksaan akhir, dan teknik balikan untuk mahasiswa. Semua persoalan tadi kerap menjadi hal yang menyulitkan bagi dosen ketika harus memeriksa isi webblog mahasiswa. Permasalahan tadi bisa dikembalikan kepada kesiapan dosen untuk menyiapkan template tertentu bagi mahasiswa. Template tadi harus menjadi pola yang wajib diikuti oleh mahasiswa dalam mengelola webblognya. Template dimaksud adalah template untuk kebutuhan memudahkan pemeriksaan yaitu menyangkut cara mengelola portofolio tugas pada akhir semester, cara susun laporan tugas, serta jadwal ketat tentang waktu pemeriksaan dan penyampaian balikan.

\section{Pengembangan Buku Panduan Pembelajaran}

Buku manual atau buku panduan untuk sebuah kegiatan resmi sangat diperlukan. Isi buku pedoman yang baik seharusnya mengandung pola tutorial yang mendasar beserta uraian tentang alasan dan tujuan kegiatan yang dilakukan. Buku pedoman seharusnya berpola tuturan visual bertahap yang memudahkan pembaca ketika akan melakukan kegiatan yang sama. Sejumlah kendala penyusunan buku panduan yang pernah ditemukan di lapangan adalah munculnya tuntutan atau langkah-langkah kegiatan yang missing. Pembaca kehilangan langkah kegiatan dalam mengikuti tutorial karena perancang panduan lebih memosisikan dirinya sebagai expert, tidak sebagai pengguna panduan.

Hal lain --di luar layout dan isi-- yang terkait dengan buku pedoman adalah format buku. Buku yang nyaman dibawa-bawa adalah buku saku. Tetapi, kelemahan buku saku ada pada ukuran ruang baca yang kurang lebar, apalagi jika berisi gambar untuk keperluan tutorial. Jika gambar yang ada dalam buku (ukuran) saku adalah gambar ilustrasi semata, sebagai penghias halaman atau sekadar gambar pelengkap naskah, kendala ukuran ruang baca tak terlalu menjadi masalah. Jika gambar yang dipasang pada setiap halaman adalah 


\section{PRASI JURNLL BAHSA, SEN, DAN PENGAHRRAWYA}

VOL. 15 | No. 01 | Juni 2020

ISSN: Print 1693-6124 - Online 2614-1116

Undiksha| DOI: http://dx.doi.org/10.23887/prasi.v15i01.24828 |https://ejournal.undiksha.ac.id/index.php/PRASI

gambar yang menjadi inti tutorial, kondisi gambar dengan ukuran kecil cukup menyulitkan untuk bisa difungsikan secara efektif. Oleh karena itu, memilih format buku pedoman dalam ukuran A5 adalah pilihan bijaksana.

\section{Focus Group Discussion dan Angket Reviewer}

"The origin of the Focus Group was in sociology. Now, FG is used intensely in the marketing field, and also, it has been growing in popularity in another areas. In social science, Robert Merton published the first work using Focus Group. Paul Lazarsfeld and others later introduced this technique in marketing" (Morgan, 1988, dikutip Lokanath Mishra dalam TechnoLEARN Vol. 6: No. 1: June 2016).

Focus Group Discussion (FGD) adalah diskusi kelompok terarah tentang topik atau persoalan khusus, yang dilaksanakan untuk mengumpulkan data (penelitian) melalui wawancara atas sejumlah orang yang memiliki kesamaan latar belakang atau keahlian. "It is a form of qualitative research where questions are asked about their (: anggota kelompok, pengutip) perceptions attitudes, beliefs, opinion or ideas" (A Herd Publication, 2016). Diskusi ini biasanya melibatkan 8 - 12 orang. Setiap anggota diskusi memiliki kebebasan untuk berbicara --dipandu oleh seorang moderator (interviewer)-dengan anggota diskusi lainnya.

Kumar, 1987, menjelaskan bahwa "The Focus Group Discussion (FGD) is a rapid assessment, semi-structured data gathering method in which a purposively selected set of participans gather to discuss issues and concerns based on a list of key themes drawn up by the researcher/facilitator". Kunci kegiatan FGD dikemukakan dalam $A$ Herd Publication sebagai berikut:

- Involves organized discussion with a selected group of individuals to gain information about their views and experiences of a topic;

- Particularly suited for obtaining several perspectives about the same topic;

- Helps in gaining insights into people's shared understanding of everyday life and the ways in which individuals are influenced by others in a group situation;

- The role of the moderator is very significant, as good levels of group leadership and interpersonal skill are required to moderate a group successfully.

Angket reviewer adalah sejumlah pertanyaan dengan jawaban tertutup dan terbuka. Jawaban tertutup untuk menjaring pendapat tentang hal yang umum, pada penelitian ini terkait dengan tampilan dan isi buku. Jawaban terbuka menyediakan kesempatan kepada reviewer untuk memasukkan pendapat pribadinya terkait dengan buku. Dua hal utama tadi menjadi alat penjaring data tentang buku secara lengkap.

\section{METODE}

Metode penelitian ini diadaptasi dari pola R\&D yang dikembangkan Dick dan Carey (2005). Sebagai gambaran alur kerja penelitian, digambarkan dalam bagan alir (bagan 2) di bawah ini. 


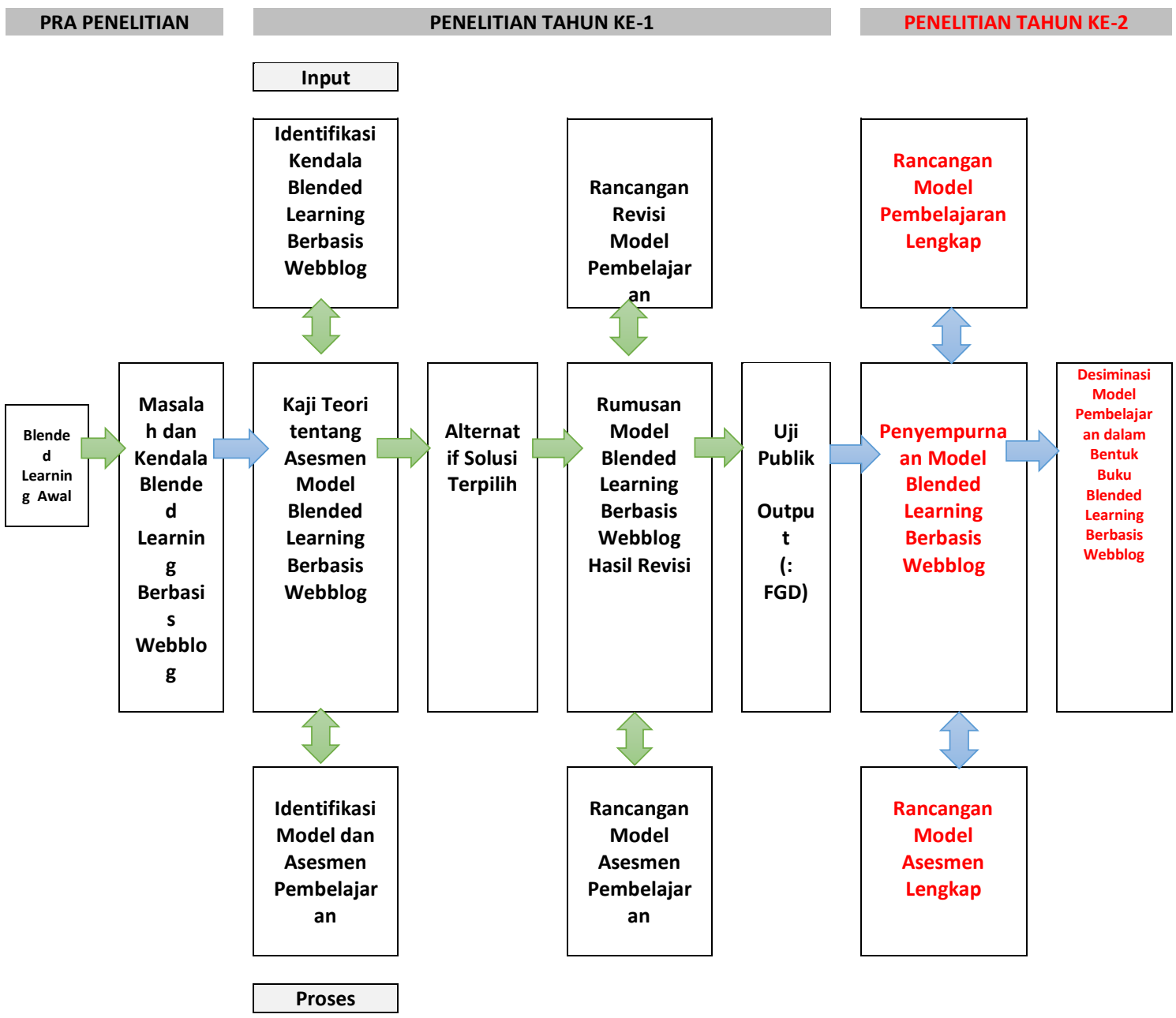

Bagan 2. Bagan Alir Rencana Kegiatan Penelitian Tahun ke-2

Data dikumpulkan menggunakan dua alat penjaring data yaitu FGD dan Angket Reviewer mendalam. FGD digunakan sebagai sarana diskusi terarah membicarakan buku pedoman hasil rancangan. Dua puluh orang dosen dari FBS menjadi peserta terpilih dalam FGD, yaitu mereka yang memiliki pengalaman dalam menulis buku (dipilih perwakilan dari semua jurusan) sekaligus sebagai calon pengguna buku ditambah ahli desain dari JSdD.

Di samping FGD, angket reviewer mendalam menjadi sarana yang digunakan untuk menjaring masukan khusus dari para ahli desain. Melalui angket reviewer ini, mereka ( 10 orang dosen dari JSdD) memberi penilaian tentang kondisi tampilan buku, isi buku, maupun keterbacaannya. Reviewer terdiri atas 10 orang reviewer buku, telah menjadi catatan sebagai bahan perbaikan tampilan dan isi buku.

\section{HASIL DAN PEMBAHASAN}

Hasil penelitian ini berupa buku pedoman model blended learning berbasis webblog yang disusun sebagai buku tutorial, lebih khusus bagi dosen. Buku dimaksud diterbitkan --sementara-- secara mandiri. Setelah mendapatkan uji-isi dari reviewer dan 
mengalami perbaikan-perbaikan isi (hasil masukan dari para reviewer), buku ini akan diterbitkan dengan jangkauan yang lebih luas.

Buku Model Blended learning Berbasis Webblog yang telah diterbitkan ini terdiri atas xxx dan 108 halaman A5. Pada bagian awal, buku ini berisi Pengantar dari Dr. Drs. I Ketut Supir, M.Hum. dengan judul Blended learning Berbasis Webblog: Menuju ke Pendidikan Praksis (xi-xxvii). I Ketut Supir juga menjadi tim peneliti dalam penyusunan buku ini. Secara keseluruhan buku ini terdiri atas 6 bab. Bab 1 s.d. 3 menceritakan perjalanan penelitian sebelumnya beserta hasil-hasilnya. Bab 4 berisi tutorial penyiapan sarana pembelajaran berbasis webblog, Bab 5 tutorial cara mengisi webblog, dan ditutup dengan bahasan Bab 6.

\section{Format Buku}

Buku panduan teruji-publik model blended learning berbasis webblog ini tersebut diharapkan bisa dimanfaatkan oleh dosen-dosen di lingkungan PD-3DKV dan PSR. Hasil revisi model pembelajaran beserta temuan-temuan masalah pada penelitian ke-1 menjadi bahan penulisan isi buku yang telah disusun pada penelitian ke-2 ini. Masukan dan pertimbangan dari tim peneliti beserta tim reviewer menjadi bahan pertimbangan pengembangan isi buku yang telah disusun.

Sejalan dengan bahasan persoalan model blended learning berbasis webblog, sebagian isi buku disusun dalam format tutorial, sebagian lagi bersifat uraian teoretis keilmuan. Pada dasarnya, isi buku bisa juga dimanfaatkan oleh dosen dari bidang studi lain. Praktik penggunaan webblog sebagai bagian dari kegiatan model blended learning dimaksud, bisa diterapkan dalam priaktik pembelajaran bidang lain. Intinya, pemanfaatan webblog sebagai kontainer tugas laporan tertulis dan dokumen kegiatan pembelajaran berupa gambar ilustrasi, foto, video, maupun animasi di PD-3DKV dan PSR, FBSUndiksha. Hasil kegiatan dalam bentuk buku ini dijadikan bahan pedoman pelaksanaan model blended learning berbasis webblog bagi dosen di lingkungan JSdD, FBSUndiksha.

Format buku A5 menjadi pilihan rancangan berkait dengan pertimbangan ergonomis. Buku format A5 dengan font Times New Roman 12 dianggap cukup nyaman untuk dibaca sebagai buku panduan, sekalipun font dipasang dengan jarak 1 spasi. Begitupun masalah gambar screenshot yang melengkapi tutorial cukup nyaman untuk dilihat dalam format buku A5. Mungkin agak mengganggu ketika perhitungan ekonomis diterapkan dalam perancangan tata letak halaman buku, karena banyak gambar yang harus dicetak berwarna. Tetapi, teknologi PoD (print on demand) telah menjawab kekhawatiran ekonomis tadi. 


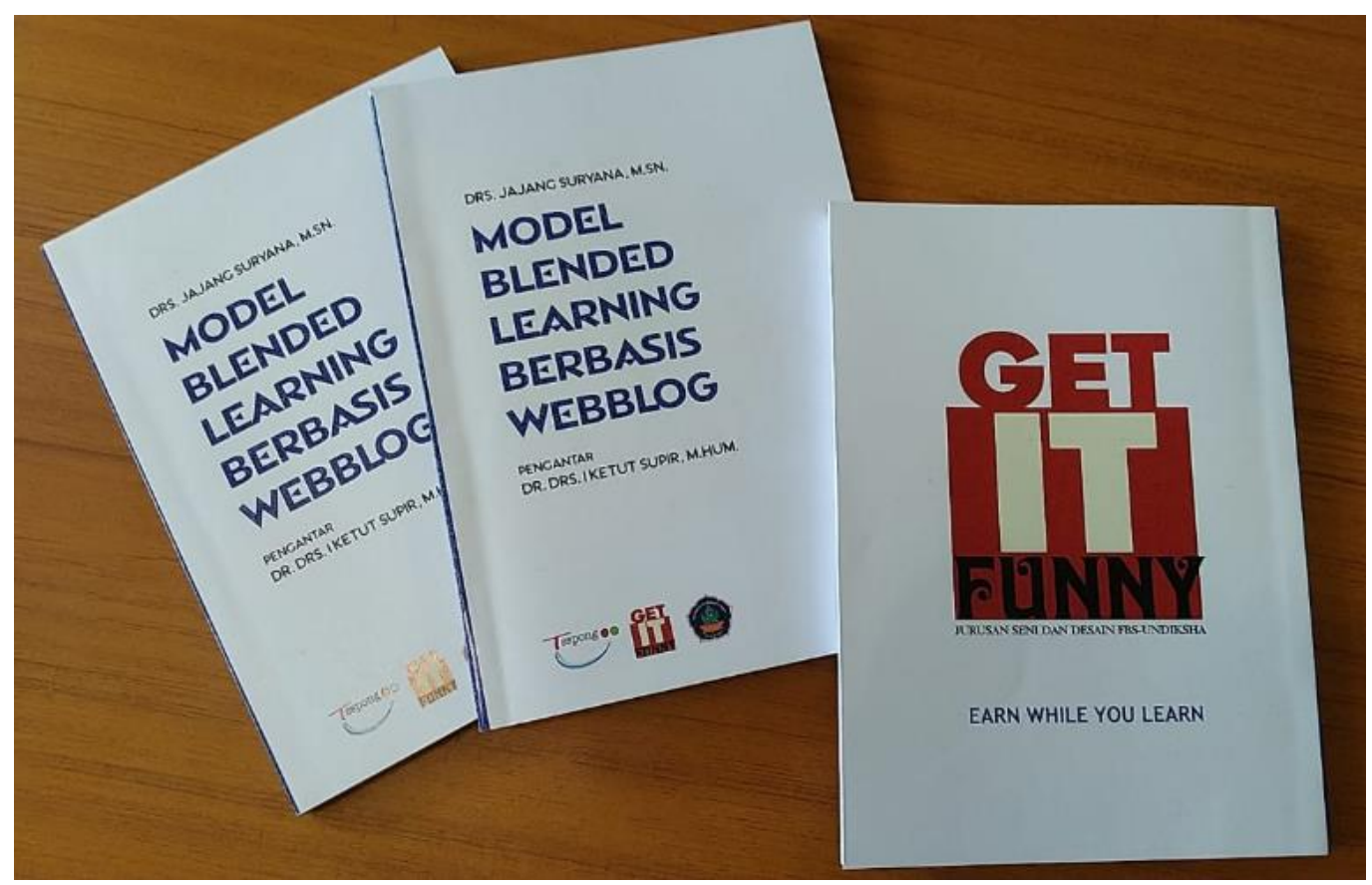

Gambar 3. Tampilan awal buku Model Blended learning Berbasis Webblog

Tampilan latar cover buku yang polos (gambar 3) dimaksudkan agar judul buku lebih mudah ditangkap secara lihatan. Pemilihan jenis huruf Napa SF Bold disejalankan dengan calon pembaca buku yaitu dosen maupun mahasiswa. Tampilan huruf Napa SF masih terasa formal sekaligus "bergaya". Hal itu diperkirakan bisa menjadi daya tarik bagi pembaca, dosen maupun mahasiswa.

Font atau huruf yang digunakan pada bagian jilid depan (cover), menurut reviewer, kurang tebal. Begitupun pemosisian huruf yang rata kiri dianggap kurang nyaman. Oleh karena itu, komposisi rata tengah menjadi pilhan akhir dari tata letak cover buku. Sementara itu, huruf yang digunakan di dalam isi buku diusulkan cukup menggunakan satu jenis huruf yang sama. Tentang isi buku, ada masukan berupa penambahan bahasan yang lebih mendalam tentang blended learning.

Di luar semua masukan tadi, reviewer sepakat, pada dasarnya model blended learning berbasis webblog yang telah dilaksanakan maupun buku pedomannya, dianggap sangat perlu sebagai bahan informasi bagi dosen lain. Sejalan dengan pelaksanaan pembelajaran berbasis IT yang menjadi tuntutan masa kini, pengembangan aneka model untuk kebutuhan sistem pembelajaran berbasis IT sejenis harus terus dilakukan. Salah satu yang bisa dijadikan model pembelajaran dimaksud adalah model blended learning berbasis webblog ini. 
PRASI IURNAL BAHASA, SENI, DAN PEngalaranNya

VOL. 15 | No. 01 | Juni 2020

ISSN: Print 1693-6124 - Online 2614-1116

Undiksha| DOI: http://dx.doi.org/10.23887/prasi.v15i01.24828 |https://ejournal.undiksha.ac.id/index.php/PRASI

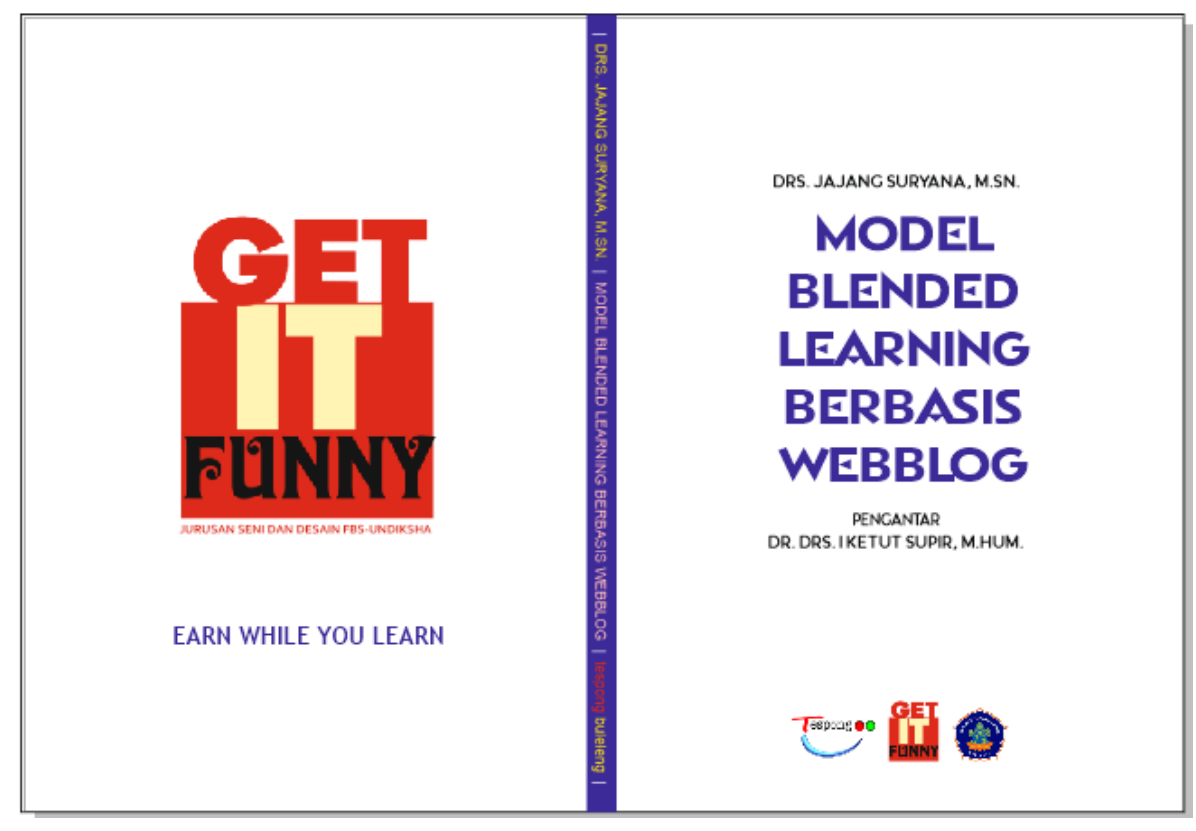

Gambar 4. Hasil perbaikan cover buku (depan dan belakang) Model Blended learning Berbasis Webblog

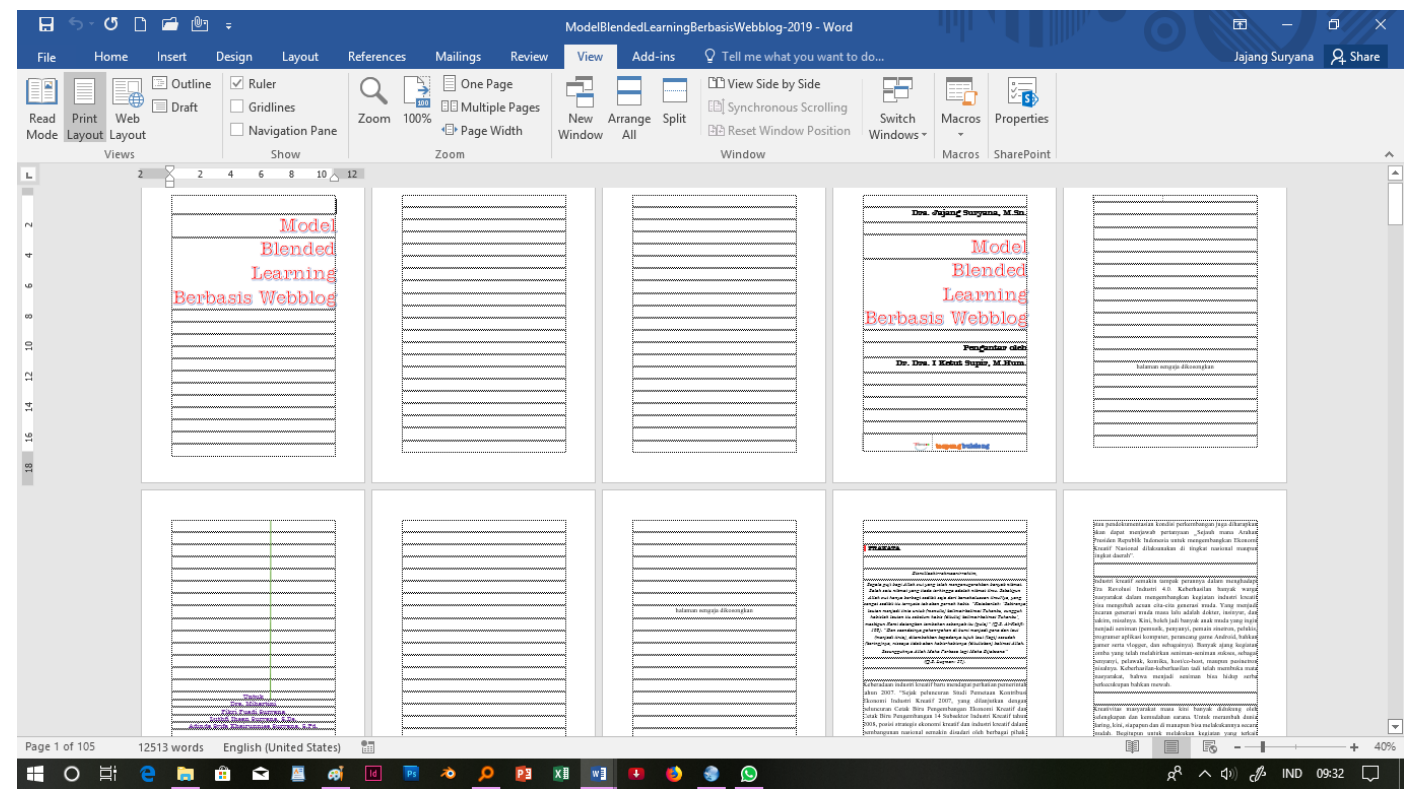

Gambar 5. Layout halaman awal buku Model Blended learning Berbasis Webblog 


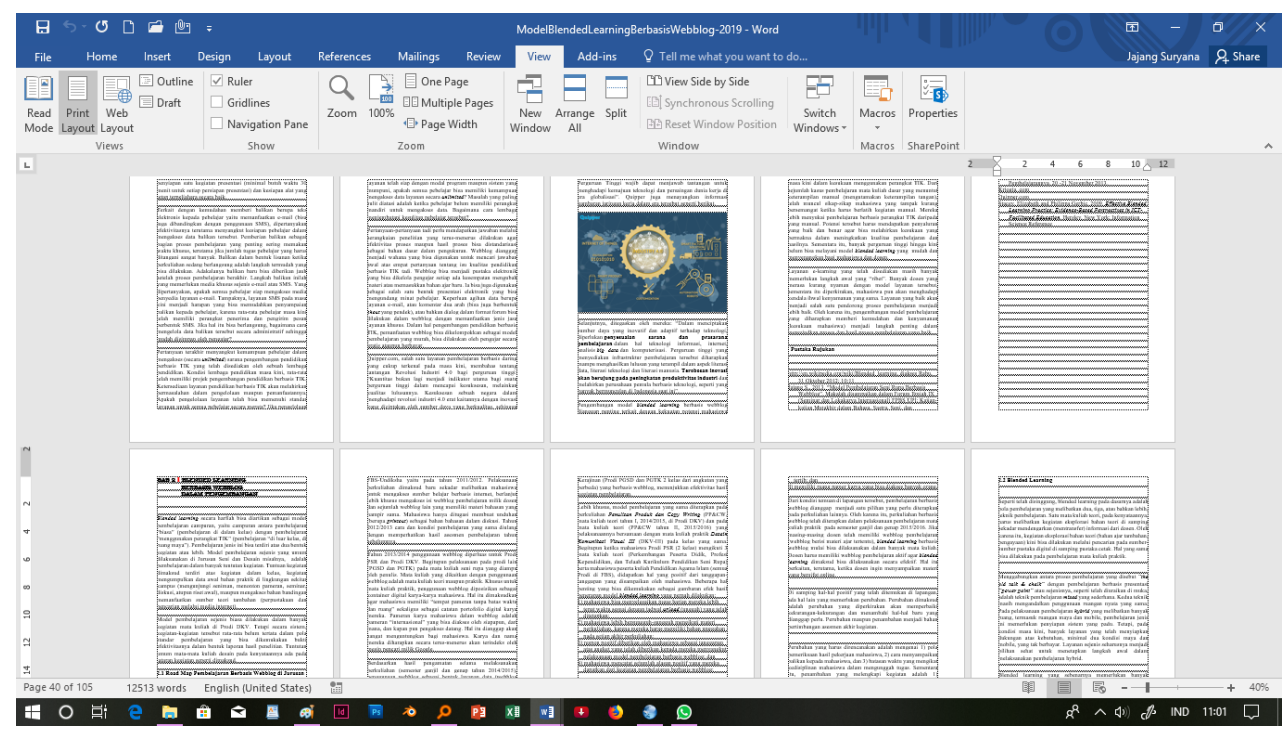

Gambar 6. Layout tampak lengkap halaman isi buku Model Blended learning Berbasis Webblog

\section{SIMPULAN}

Simpulan hasil penelitian pengembangan ini adalah format buku panduan pelaksanaan blended learning berbasis webblog adalah A5. Buku pedoman model blended learning berbasis webblog setelah mengalami perbaikan mengacu kepada masukan para reviewer, berisi bahasan teoretis model-model blended learning, rangkuman hasil pengembangan penelitian pelaksanaan blended learning berbasis webblog, dan tutorial pelaksanaan blended learning berbasis webblog yang telah disempurnakan.

Beberapa hal yang perlu disarankan terkait dengan pelaksanaan blended learning berbasis webblog adalah Sistem E-learning yang disediakan oleh lembaga (Undiksha) sejauh ini telah memiliki pilihan layanan webblog, tetapi tampaknya belum termanfaatkan oleh dosen, apalagi mahasiswa. Jika webblog dimaksud sama dengan layanan $e$-mail yang telah diintegrasikan dengan layanan dari Google, hal itu akan sangat bermanfaat bagi dosen maupun mahasiswa. Pada layanan website perguruan tinggi lain sebagai bandingan di UPI dan UM (Universitas Negeri Malang), integrasi layanan webblog dengan Google telah dilakukan. Hal itu mempermudah sekaligus memperlancar proses pemanfaatan webblog sebagai sarana belajar. Yang tak kalah penting, semua bentuk penggunaan perangkat TIK yang telah terintegrasi dengan website lembaga akan menjadi nilai tambah bagi kondisi website tersebut.

Layanan berbayar bisa menyediakan kelebihan janji sisi keamanan. Pemanfaatan layanan tersebut tentu menjadi sangat ideal. Tetapi, jika ada layanan tak berbayar dengan kondisi keamanan yang baik, pemanfaatan layanan tersebut menjadi sangat bijaksana. Terutama, ketika jumlah klien (mahasiswa) sangat banyak, yang tidak memungkinkan mendapatkan layanan berbayar penuh. Pemanfaatan vendor yang tak berbayar menjadi kesempatan emas sebagai sarana latihan yang sangat murah bagi mahasiswa. Peningkatan layanan dengan layanan berbayar bisa dilakukan pada saat mahasiswa atau juga lembaga 
telah menemukan posisi "harus sangat profesional" terutama ketika syarat menghadirkan kepercayaan kepada stake holder menjadi tuntutan utama.

\section{DAFTAR PUSTAKA}

Chiesa, Vittorio \& Federico Frattini. 2009. Evaluation and Performance Measurement of Research and Development Techniques and Perspectives for Multi-Level Analysis. Massachusetts: Edward Elgar Publishing, Inc.

Darmawangsa, Dante. 2014. "Implementasi Teknik Menulis Kolaboratif Melalui Blog untuk Meningkatkan Ketrampilan Menulis Bahasa Perancis”. Dimuat dalam Barista, Vol. 1, Nomor 2, Desember 2014.

Dick, Walter, Lou Carey, and James O. Carey. 2005 [1978]. The Systematic Design of Instruction (6th ed.). Allyn \& Bacon.

Horn, Michael B. and Heather Staker. 2014. Blended: Using Disruptive Innovation to Improve Schools 6. Dapat ditemukan di https://www.blendedlearning.org/ models/

Jajang S., 2013. “Model Pembelajaran Seni Rupa Berbasis Webblog”. Makalah disampaikan dalam Forum Ilmiah IX (Seminar dan Lokakarya Internasional) FPBS UPI: Kajian-kajian Mutakhir dalam Bahasa, Sastra, Seni, dan Pembelajarannya. 20 -21 November 2013.

Jajang, Hariwardana, dan Herliyani. 2015. Analisis Visual Graphical User Interface (GUI) Website Universitas Negeri Eks. IKIP: Bahan Pengembangan Materi Ajar Desain Komunikasi Visual Berbasis Pendidikan Karakter. Laporan Penelitian Lemlit Undiksha.

Kumar, K. 1987. “Conducting focus group interviews in developing countries”. A.I.D. Program Design and Evaluation Methodology Report No. 8. Washington, D.C.: U.S. Agency for International Development.

Lalima \& Dangwal. 2017. Blended learning: An Innovative Approach. Universal Journal of Educational Research 5(1): 129-136, 2017 http://www.hrpub.org DOI: 10.13189/ujer.2017.050116

Sunismi dan Abdul Halim Fathani, 2017. "Pengembangan Model Collaborative Learning Matemetika Berbasis Blog Mata Kuliah Kalkulus II”. Makalah pada Seminar Nasional Matematika dan Aplikasinya, Surabaya, Unair, 21 Oktober 2017. TechnoLEARN Vol. 6: No. 1: June 2016 